\title{
TECHNOLOGY AND ECONOMIC DEVELOPMENT: RETROSPECTIVE
}

\author{
Prof. Krume Nikoloski PhD \\ Goce Delchev University - Stip, Republic of Macedonia \\ e-mail: krume.nikoloski@ugd.edu.mk
}

\author{
Professional Paper \\ $\underline{\text { doi:10.5937/jouproman4-11468 }}$
}

\begin{abstract}
The purpose of this paper is to represent historical link between technological progress and economic development. Furthermore, the reasons are aimed at presenting the stages of development of technological progress and its contribution to economic development, particularly in changing economic and social life. I want to emphasize that many researchers of scientific thought, technological progress has been learned as one of the root causes of cyclical movement of capitalist economy. Others seek to quantify the share of technological progress in the rate of GDP growth. Also, in this paper are going to be analyzed the importance of technological progress in society and will be given a chronological framework for the role and importance of the scientific and technological revolutions.
\end{abstract}

Keywords: technological progress, economic development, technological revolutions.

\section{Introduction}

The term technique comes from the Greek word (tehne), and it means: skill, ability, skill, knowledge, means and instrument. In the recent time, it is the accumulated knowledge and experience that is generated in all areas of society. While the term technology comes from two Greek words: tehno and logos (science). It is a science to the sum of knowledge about procedures and processes used in the manufacture of material production. Later the term technology has been extended in a double sense: first, covers the sum of knowledge about procedures and processes not only in manufacturing but also in other spheres of social life and, secondly, includes the procedures and processes. Historically, Colin Clark and Jean Fourastié are the first economic thinkers who emphasize the role of technological progress and its impact on economic progress or development. When discussing technological development, and to have no doubt, think of the changes that are produced under the influence of interacting relations in society and technological progress. And all this affect the social and economic behavior in everyday life.

While the spectrum of opinion represented in these discussions is quite broad, there seem to be some points of consensus, at least within the Western "mainstream"(Bostroam, Nick 2006):

- Technological development will have major impacts on human society.

- These developments will create both problems and opportunities.

- "Turning back" is neither feasible nor desirable.

- There is a need for careful public examination of both the upsides and downsides of new technologies, and for exploration of possible ways of limiting potential harms (including technological, regulatory, intergovernmental, educational, and community-based responses). 


\section{Technological progress and economic development}

Today, technological progress becomes a factor in economic growth and development, but in some countries it varies according to the intensity and forms of realization.

Its main components are:

- Discovery (invention),

- The application of the innovation and

- Diffusion of other entities.

Besides these components, some researchers emphasize factor aging (degradation) of the invention. In a scientific thought three main stages of technological progress are distinguished manually production (up to the first industrial revolution), machine-industrial system and age of automation. It is about different points of view in the discussion stages of technological progress distinguished between four scientific and technological revolutions.

The first industrial revolution is caused by working of the steam engine or replacing of a manufacture system with an industrial system design (industrial age).When it started at the end of the XVIII century, caused a number of changes in the economic and social life and led to replace some of the physical effort with machines, allow hiring of female and child labor, increase the universality of workers in terms that can be employed and adapted to perform different activities, increased unemployment, increased the level of concentration of production and has increased imbalances in the development of economic branches and regions (Stojkov, 2008).

Second industrial or electromechanical revolution refers to automation. Simply, automation enables strengthening of nationwide economies. It refers to the employee transfer in the field of direct manufacturing and went to the fields before and after production. Automating changes man and human development not only in the execution of physical operations, but also in the performance of certain mental operations. Also central to the changes of this revolution are electricity and its application in electric motors, telephone, telegraph, automobile, aircraft and others.

The third industrial or technological revolution began before World War II and it's called electronic revolution. At the heart of the changes is a transistor whose application enable the development of computers or computers and microprocessors.

Finally, it is discussed about the fourth technological revolution that began late last century and which is also called an information revolution. The key for this revolution is the chip. A chip is directly linked to high technology - information technology non-informational robots and other forms i.e. machines and tools with numerical control. Technological revolution caused major changes in biotechnology, energy resources and raw materials. Among other things, it causes the replacement of national economies with the global economy and remarkable passage of workers in the services sector.

The literature devoted to the technological progress depicts three basic types of technological progress:

1. Labor intensive (larger investments in labor rather than capital),

2. Capital-intensive (larger equity investments compared with investments in workforce), and

3. Neutral technological progress (equal increase in investments capital and labor).

This division is made according to the relationship between capital and labor in the realization of production (the macro level of GDP growth). 
In practice more individual indicators are used to measure technological progress.

For example, the height of the global productivity is used as a synthetic indicator of technological progress, which is calculated using the Cobb-Douglas production function. Technological progress causes major changes in other factors of production, particularly in labor and capital. It causes significant changes in the area of international competition where the countries that offer high technology had bigger advantage (Stojkov 2008). Technological progress is among the major factors that enhance the process of globalization in the world. In this context, it points out that electronic and Internet services revolution is leading to the formation of the Internet economy. And also contribute to increase the connectivity of the world economy. Because of the technological development rate's great importance in order to have economic growth and broader economic development, there are many efforts to involve technological development in newer models of economic growth recently. Special merit for this plan deserved Robert Solow and Paul Romer.

Important factors that affect the economic growth:

- Natural Resources

- Human Resource

- Capital Formation

- Technological Development

- Social and Political Factors

Technological revolution can cause the productions possibility frontier and initiate economic growth.

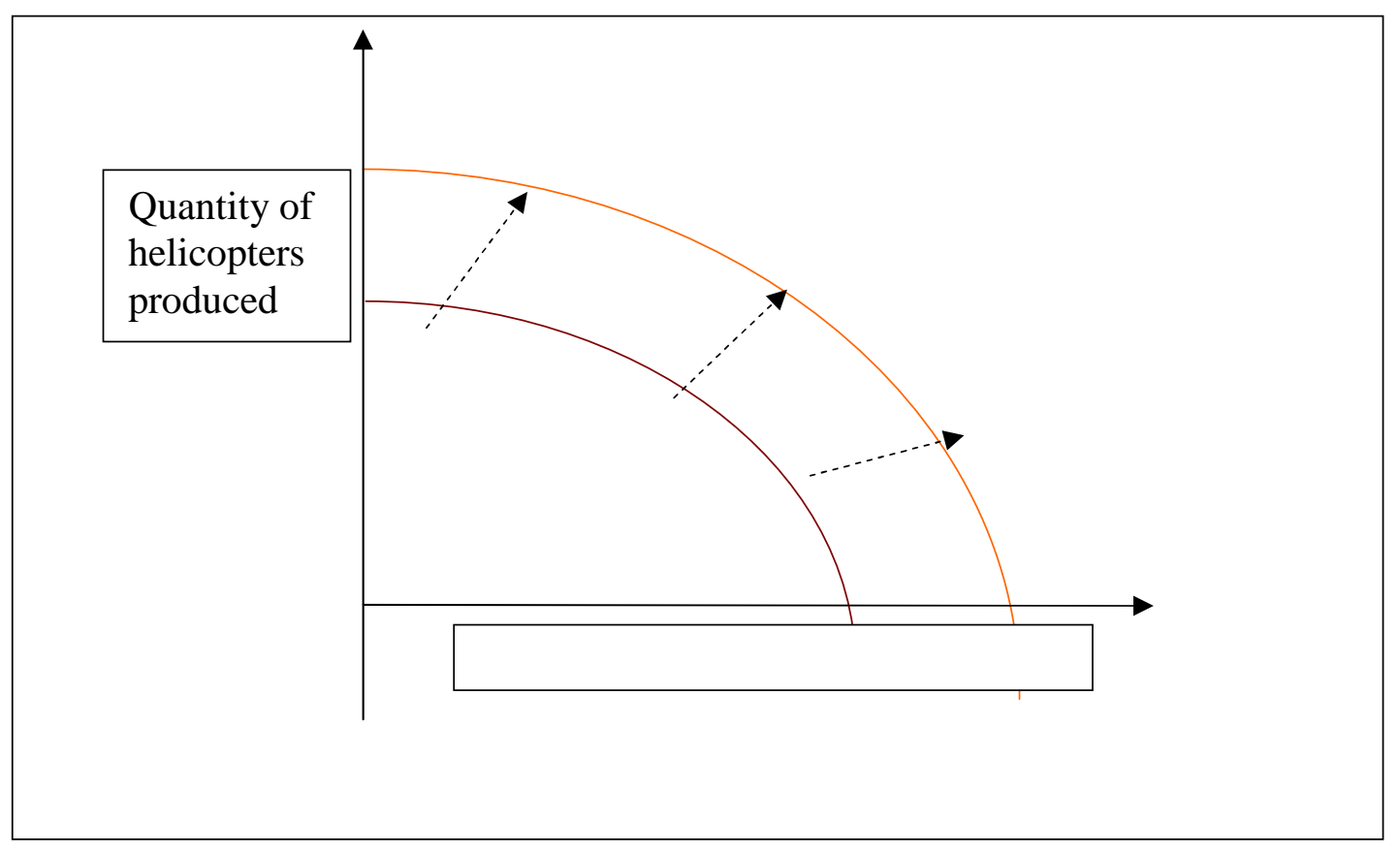

Figure: 1. Productions possibility frontier and initiate economic growth

In respect of technological development, technological advances provide increased productivity. From a special importance is the innovative advances. There are other important categories:
- Energy

- Transportation and Industrial Machinery

- Communication

- Logistics 
Namely, the theme "Innovating in the Digital Economy," The Global Information Technology Report 2016 highlights the ways in which the digital revolution is changing both the nature of innovation and the rising pressure for firms to innovate continuously. The main focus in this report are four key findings:

1. The digital revolution changes the nature of innovation.

2. Firms will face increasing pressure to innovate continuously.

3. Businesses and governments are missing out on a rapidly growing digital population.

4. A new economy is shaping, requiring urgent innovations in governance and regulation.

A detailed analysis of these four findings are presented in the report.

In highlighting the role of technological development for economic development one can swim in the waters of technological determinism. Namely, economic development can be explained only by the benefits of technological progress in innovations and to believe that they will solve all the problems of humanity.

According to me, these are ten hightech breakthroughs ranked as follows:

- The Internet

- Genetic engineering

- Personal computers

- Digital media

- Electronic funds transfer

- Mobile phones

- Space flight

- Nuclear power

- Robots and artificial intelligence

- Organ transplants

Technology Transfer

It's very complex and polidimensional concept. For this concept are given either very general or partial definitions. The general definition states that the transfer of equipment and technology amounts to a transfer of technology and knowledge from where you they are created or complement to the place where they should be used. In that sense, the transfer can take place between countries or between regions within a country. In more specific definitions says that despite the transfer of technology and knowledge, the user should be able to have the conditions for creating proprietary technology and its diffusion. The main purpose of the transfer of technology is to accelerate the technological and economic development. Otherwise, it may be horizontal and vertical and may take place in different channels. According to some authors, the channels can be grouped into three groups:

1. The elements of industrial property (patents, protected brands and models and so on.),

2. Know-how technical improvements and,

3. Other forms (equipment, production cooperation, technical assistance, joint ventures.).

Today in the area of technological development worldwide there is a very refined technological gap between developed countries on the one hand and developing countries on the other. Specifically, in that domain the developing countries is trailing significantly (several times) behind developed countries. A recently mentioned technological gap is widening to the detriment of developing countries. Both types are most emphasized in high technology (ICT) and it can easily be demonstrated by means of adequate statistics. The lag of the developing countries in the area of technological development is also reflected in other domains of social life, and in relations between developed countries and them. In that context is the technological dependence of the developing from developed ones. 
It derives from the fact that the developing countries are the producers of modern equipment and technology, and if they want to grow, they need to be supplied from abroad (from developed countries), and under the conditions that are laid down (dictated) by developed countries (Stojkov, 2008).

Today, developed countries have a monopoly on the sources of technological development and export of modern equipment and technology while developing countries are technologically dependent on developed countries. The degree of technological dependence is greater if a country occurs only as an importer of equipment and technology, and that example is thus the developing countries (Todorov, 2002).Technological dependency also exists between the leaders of technological development, on the one hand, and other less developed countries of the leaders on the other. But those countries are exporters in some areas and are importers of equipment and technology in others, so they've got a lower level of technological dependency, compared with countries that only import equipment and technology (developing countries).

\section{Conclusion}

Many economists and researchers learn technological progress as one of the root causes of:

- Cyclical movement of capitalist economy;

- Others seek to quantify the share of technological progress in the rate of GDP growth;

- Learn the importance of technological progress in the information society;

- Express the scientific and technological revolutions.

After World War II a separate discipline is formed with different names: the policy of technological development, scientific and technological progress and so on. In terms of technological development a key contribution have policy makers. Specifically, technological policy should refer to goals and priorities particularly, determining the technological policy subject, the establishment of instruments and means of implementation of objectives and analysis of the results, and at last proposing measures to improve the situation. Often as its main aims and objectives are suggested the following: the transition to a higher technological and development phase, providing sustainable development where crucial importance have investment and education, involvement in the process of globalization, development of national innovation systems, more expressed orientation towards human potential in terms of capital.

\section{Reference}

[1] Bostroam, Nick (2006). Technological revolutions: Ethics and Policy in the Dark, Nanoscale: Issues and Perspectives for the Nano Century, Nigel M. de S. Cameron and M. Ellen Mitchell. John Wiley, pp. 129-152. Also available at: http://www.nickbostrom.com/revolutions.pdf;

[2] Bloomfield, Masse. (1995).The Automated Society. Masefield Books.

[3] Caselli, Francesco. (1999) "Technological Revolutions." American Economic Review, 89(1): 78-102. Also available at: http://personal.lse.ac.uk/casellif/papers/techrev .pdf;

[4] Landreth, H., \& Colander, D. (2002). History of Economic Theory. Houghton Mifflin;

[5] MacKensie, D. and Wajcman, J. (1985). The Social Shaping of Technology, Milton Keynes. Open University Press;

[6] Todorov T. (2002). "Economic theories and economic thought", Faculty of Economics - Prilep;

[7] Skousen, M. (2001). The Making of Modern Economics. ME Sharpe; 
(JPMNT) Journal of Process Management - New Technologies, International Vol. 4, No.4, 2016.

[8] Stojkov, M. (2008). Development of Economic Thought, Faculty of Economics Skopje;

[9] www.weforum.org/agenda/2015/ 02/are-you-ready-for-the-technologicalrevolution/;

[10] Impacts of Technological Change on Productivity." Boundless Economics. Boundless, 26 May. 2016. Retrieved 22 Sep. 2016. also available at: (https://www.boundless.com/economics/textbo oks/boundless-economics-textbook/economicgrowth-20/productivity-98/impacts-oftechnological-change-on-productivity-370$\underline{12467 /)}$;

[11] The Global Information Technology Report 2016, World Economic Forum, 2016. also available at:https://www.weforum.org/reports/theglobal-information-technology-report-2016/; 